\title{
Perceptions of Surgical and Other Medical Specialties about Medical Oncologists: A Survey among Physicians in a Filipino Tertiary Hospital
}

\author{
Jamila Marie J. De Veyra ${ }^{1, \odot ~ C l e v e l i n d a ~ S . ~ C a l m a ~}{ }^{1}$ \\ ${ }^{1}$ Department of Internal Medicine, Section of Medical Oncology, \\ Benavides Cancer Institute, University of Santo Tomas Hospital, \\ Manila, Philippines
}

\begin{abstract}
Address for correspondence Jamila Marie J. De Veyra, MD, Benavides Cancer Institute, University of Santo Tomas Hospital, Manila 1015, Philippines (e-mail: jamiedeveyra9184@gmail.com). Clevelinda S. Calma, MD, Room 420 Clinical Division Bldg., University of Santo Tomas Hospital, A.H. Lacson St., Manila 1015, Philippines (e-mail: bingcalma@gmail.com).
\end{abstract}

\begin{abstract}
Keywords

- medical oncology

- oncologist

- patient care

- Philippines

- physicians

- referral and consultation

- surveys and questionnaires

Introduction There are unverified negative perceptions about medical oncologists. Identifying how they are perceived may provide guidance on how to strengthen the positive and correct the negative impressions.

Methods Questionnaires were distributed to 528 physicians. They were asked to answer a Likert scale of opposing descriptors.

Results Two hundred and fifty-nine of 528 physicians completed the questionnaire, yielding a $49 \%$ response rate. Medical oncologists were perceived to have a medical rather than social focus to their work, render holistic care, have a multifaceted role, communicate with many other professionals, work more effectively in a team, have deep relationships with patients, and care for their general well-being. They are considered to be the nonsporty, intellectual type, who do not consider themselves superior, but rather treat other physicians as colleagues. They are perceived to not only have the skills to deal with a psychiatric problem and a wide spectrum of patients, have a health education role, require a high level of intellectual skills, collaborate more with others, possess good interpersonal skills with an individual patient, but are also adept within a group. They are autonomous workers, but usually refer patients to other professionals as well. Lack of finances hinders referral to medical oncologists.

Conclusion Perceptions were generally positive in terms of breadth of professional outlook, degree of patient interaction, projected professional image, perception of own professional status, possession of skills for a wide professional scope of responsibility, level of rapport with patient and colleagues, and degree of professional interdependence. Mainly financial factors are the barriers to referral to medical oncologists.
\end{abstract}

\section{Introduction}

Medical oncology has been recognized as a specialty in the Philippines since 1969, with the establishment of the Philippine Society of Medical Oncology (PSMO). However, as

published online

May 11,2021
DOI https://doi.org/

$10.1055 / \mathrm{s}-0041-1729345$

ISSN 2454-6798 of May 2018, there are only 234 medical oncologists, servicing the 16 regions of the entire Philippines. ${ }^{1}$ There is a disproportionate ratio of medical oncologists to the greater majority of cancer-stricken Filipinos because only a determined minority choose to and are qualified to be medical oncologists. (c) 2021. Spring Hope Cancer Foundation \& Young Oncologist Group of Asia.

This is an open access article published by Thieme under the terms of the Creative Commons Attribution-NonDerivative-NonCommercial-License, permitting copying and reproduction so long as the original work is given appropriate credit. Contents may not be used for commercial purposes, or adapted, remixed, transformed or built upon. (https://creativecommons.org/licenses/by-nc-nd/4.0/).

Thieme Medical and Scientific Publishers Pvt. Ltd. A-12, 2nd Floor, Sector 2, Noida-201301 UP, India 
There is an unverified perception among patients and even doctors that medical oncologists are only chemotherapists or worse "drug pushers," and that patients diagnosed with metastatic disease can no longer be offered chemotherapy or any other systemic treatment, apart from best supportive care.

Medical oncology is largely based on a referral system, meaning that majority of patients seen by medical oncologists come from another doctor, usually from the surgical specialties, already bearing a biopsy result confirming the diagnosis of cancer. Thus, it is important that other medical and surgical specialties are well-aware of the medical oncologist's job description and role in the multidisciplinary cancer team, especially since a multidisciplinary approach to malignant diseases is the basis for optimal-quality patient care. ${ }^{2}$

Wrong impressions about what a medical oncologist can do and offer may lead to gaps in the cancer patient's management, especially if the primary attending physician chooses not to refer to the medical oncologist at all, due to various reasons. This article aims to identify the perceptions of surgical and other medical specialties about medical oncologists. Identifying how other doctors see medical oncologists will guide the medical oncology society to strengthen the positive notions, improve on its weaknesses, and debunk any misconceptions. A better understanding among specialties would promote a more productive collaboration in the proper and adequate treatment and care for the cancer patient.

\section{Materials and Methods}

\section{Subjects}

From May to July 2019, questionnaires were distributed to 318 medical staff (consultants) and 210 medical trainees (154 residents and 56 fellows) affiliated with the University of Santo Tomas (UST) Hospital, Manila, Philippines. Respondents belonged to the following departments: dermatology, family medicine, internal medicine, neurology and psychiatry, obstetrics and gynecology, ophthalmology, orthopedics, otorhinolaryngology-head and neck surgery, radiation oncology, rehabilitation medicine, and surgery.

\section{Questionnaire}

The 19-item questionnaire was adapted from the Role Perception Questionnaire (RPQ) by Stuart MacKay (2004), utilizing a 10-point Likert scale positioned between two columns of opposing descriptors. Permission to use the questionnaire was granted by Dr. MacKay through e-mail correspondence. Respondents were instructed to encircle the number on the scale closest to the characteristic, either on the left or the right side, that represented their views. The second page of the questionnaire allowed respondents to write down other attributes (positive or negative) that they would use to describe medical oncologists, not listed among the choices in the questionnaire. Respondents were allowed to cite possible hindrances in referring to medical oncologists, if any. A space was provided for other comments.

\section{Statistical Analysis}

All data were collected, stored, and analyzed using IBM SPSS Statistics for Windows (Version 21.0. Released 2012. Armonk,
NY: IBM Corp.) Means, standard deviations, and frequencies were computed. Independent $t$-test was done to determine any significant difference between the mean rating scores of surgical versus medical specialties.

\section{Results}

\section{Response Rate}

Two hundred and fifty-nine of 528 physicians completed the $\mathrm{RPQ}$ yielding a $49 \%$ response rate.

\section{Responses}

As seen in - Table 1, majority of physicians (80.8\%) responded that medical oncologists collaborate considerably with others. Medical focus to work was considered more than social focus ( $45.9 \%$ vs. $17.3 \%$, respectively), but a close percentage gave equal weight of medical and social focus (36.8\%).

Medical oncologists were perceived by most as having a holistic view (69.3\%), building a deep relationship with the patient (76.9\%), having a multifaceted role (61.9\%), and communicating with many professionals (72.1\%).

Half of the respondents (50.4\%) reported that medical oncologists work autonomously; one-third (32.5\%) consider that they are between working autonomously and having their practice directed or supervised by other physicians.

Majority (60.8\%) of the respondents considers medical oncologists to have an objective medical perspective; one-third (30.4\%) consider a balance between an objective and subjective point of view. Respondents mostly characterized medical oncologists to possess good interpersonal skills with an individual patient (43\%), but one-third believe that they equally demonstrate good interpersonal skills within a group situation (36.3\%).

Half of the respondents (54.5\%) believe that medical oncologists possess skills which enable them to deal with a psychiatric problem, but one-fourth (26.2\%) respondents think otherwise.

Majority of the respondents (69.2\%) believe that medical oncologists work more effectively in a team. Most respondents (47.1\%) stated that medical oncologists usually refer a patient to another professional, but one-fourth (26.9\%) think that they work with the patient within their own professional field of knowledge, while one-fourth (26\%) chose in between the two qualities.

Medical oncologists are generally considered to carry a nonsporty, more intellectual image by most (60.8\%) respondents, but balanced between sporty and intellectual as per one-third of respondents (31.4\%). They are deemed able to deal with a wide spectrum of patient types by $67 \%$ of the respondents. They tend to work well in a team per $69.2 \%$ of the respondents. A significant number of respondents (24.5\%) believe that medical oncologists can work both in a team and in isolation.

Majority of the respondents view medical oncologists as having a health education role (78\%), having a high level of intellectual skills (59.8\%), treating other professionals as colleagues (67.5\%), and caring for the patient's general well-being (76.1\%). 
Table 1 Perceptions of medical oncologists and percentages of rating

\begin{tabular}{|c|c|c|c|c|c|c|}
\hline & & & & Rating & & \\
\hline & Rating of 1 & Rating of 10 & $\begin{array}{l}\text { Mean } \pm \text { SD } \\
\text { rating score }\end{array}$ & $1-4$ & $5-6$ & $7-10$ \\
\hline Q1 & $\begin{array}{l}\text { Has a specific role which } \\
\text { involves little collabora- } \\
\text { tion with others }\end{array}$ & $\begin{array}{l}\text { Collaborates considerably } \\
\text { with others }\end{array}$ & $7.87 \pm 2.21$ & $10.2 \%$ & $9.0 \%$ & $80.8 \%$ \\
\hline Q2 & $\begin{array}{l}\text { Medical focus to their } \\
\text { work }\end{array}$ & Social focus to their work & $4.61 \pm 2.08$ & $45.9 \%$ & $36.8 \%$ & $17.3 \%$ \\
\hline Q3 & $\begin{array}{l}\text { Has a holistic view of the } \\
\text { patient }\end{array}$ & $\begin{array}{l}\text { Only concerned with } \\
\text { their own practice related } \\
\text { problem }\end{array}$ & $3.61 \pm 2.53$ & $69.3 \%$ & $12.5 \%$ & $18.2 \%$ \\
\hline Q4 & $\begin{array}{l}\text { Builds a deep relation- } \\
\text { ship with the patient }\end{array}$ & $\begin{array}{l}\text { Has a more superficial } \\
\text { relationship with the } \\
\text { patient }\end{array}$ & $3.09 \pm 2.28$ & $76.9 \%$ & $12.9 \%$ & $10.3 \%$ \\
\hline Q5 & Has a multifaceted role & Has a specific focused role & $4.15 \pm 2.7$ & $61.9 \%$ & $15.1 \%$ & $23.0 \%$ \\
\hline Q6 & $\begin{array}{l}\text { Communicates with } \\
\text { many professionals }\end{array}$ & $\begin{array}{l}\text { Communicates with few } \\
\text { other professionals }\end{array}$ & $3.41 \pm 2.48$ & $72.1 \%$ & $11.8 \%$ & $16.1 \%$ \\
\hline Q7 & Works autonomously & $\begin{array}{l}\text { Has their practice directed } \\
\text { or supervised by another } \\
\text { professional }\end{array}$ & $4.42 \pm 2.21$ & $50.4 \%$ & $32.5 \%$ & $17.1 \%$ \\
\hline Q8 & $\begin{array}{l}\text { Has an objective medical } \\
\text { perspective }\end{array}$ & $\begin{array}{l}\text { Has a subjective social } \\
\text { perspective }\end{array}$ & $3.85 \pm 2.09$ & $60.8 \%$ & $30.4 \%$ & $8.8 \%$ \\
\hline Q9 & $\begin{array}{l}\text { Possess good inter- } \\
\text { personal skills with an } \\
\text { individual patient }\end{array}$ & $\begin{array}{l}\text { Demonstrate good inter- } \\
\text { personal skills within a } \\
\text { group situation }\end{array}$ & $4.75 \pm 2.38$ & $43.0 \%$ & $36.3 \%$ & $20.7 \%$ \\
\hline Q10 & $\begin{array}{l}\text { Does not possess skills } \\
\text { to deal with a psychiatric } \\
\text { problem }\end{array}$ & $\begin{array}{l}\text { Possess skills which enable } \\
\text { them to deal with a psy- } \\
\text { chiatric problem }\end{array}$ & $6.46 \pm 2.22$ & $19.3 \%$ & $26.2 \%$ & $54.5 \%$ \\
\hline Q11 & $\begin{array}{l}\text { Works effectively in a } \\
\text { team }\end{array}$ & $\begin{array}{l}\text { Works more effectively } \\
\text { alone }\end{array}$ & $3.55 \pm 2.35$ & $69.2 \%$ & $17.6 \%$ & $13.2 \%$ \\
\hline Q12 & $\begin{array}{l}\text { Usually refers a patient } \\
\text { to another professional }\end{array}$ & $\begin{array}{l}\text { Works with the patient } \\
\text { within their own profes- } \\
\text { sional field of knowledge }\end{array}$ & $4.75 \pm 2.53$ & $47.1 \%$ & $26.9 \%$ & $26.0 \%$ \\
\hline Q13 & Has a sporty image & $\begin{array}{l}\text { Nonsporty more intellec- } \\
\text { tual image }\end{array}$ & $7.05 \pm 1.92$ & $7.8 \%$ & $31.4 \%$ & $60.8 \%$ \\
\hline Q14 & $\begin{array}{l}\text { Is able to deal with } \\
\text { a wide spectrum of } \\
\text { patient/client types }\end{array}$ & $\begin{array}{l}\text { Is able to deal with only a } \\
\text { narrow range of patient/ } \\
\text { client types }\end{array}$ & $3.62 \pm 2.3$ & $67.0 \%$ & $18.8 \%$ & $14.2 \%$ \\
\hline Q15 & $\begin{array}{l}\text { Tends to work in } \\
\text { isolation }\end{array}$ & Tends to work in a team & $7.08 \pm 2.16$ & $12.6 \%$ & $24.5 \%$ & $62.8 \%$ \\
\hline Q16 & $\begin{array}{l}\text { Has a health education } \\
\text { role }\end{array}$ & $\begin{array}{l}\text { Role is unrelated to health } \\
\text { education }\end{array}$ & $3.07 \pm 2.21$ & $78.0 \%$ & $11.9 \%$ & $10.0 \%$ \\
\hline Q17 & $\begin{array}{l}\text { Requires a high level of } \\
\text { technical skill }\end{array}$ & $\begin{array}{l}\text { Requires a high level of } \\
\text { intellectual skills }\end{array}$ & $6.93 \pm 2.29$ & $12.7 \%$ & $27.4 \%$ & $59.8 \%$ \\
\hline Q18 & $\begin{array}{l}\text { Acts as superior to other } \\
\text { professionals }\end{array}$ & $\begin{array}{l}\text { Treats other professionals } \\
\text { as colleagues }\end{array}$ & $7.35 \pm 2.29$ & $13.8 \%$ & $18.7 \%$ & $67.5 \%$ \\
\hline Q19 & $\begin{array}{l}\text { Cares for the patient's } \\
\text { general well-being }\end{array}$ & $\begin{array}{l}\text { Cares for the patient only } \\
\text { in relation to their specific } \\
\text { professional context }\end{array}$ & $3.15 \pm 2.39$ & $76.1 \%$ & $12.1 \%$ & $11.8 \%$ \\
\hline
\end{tabular}

Note: Among total medical doctors $(n=259)$.

The data was weighted to represent the distribution of the population of medical doctors in the University of Santo Tomas Hospital. The data are presented as mean and standard deviation of the rating scores, as well as the percentages of the agreed rating scores (1-4, 5-6, and 7-10); values in bold are subjective based on the highest frequency of scores from the respondents. 
A visual representation of the these ratings is shown in

-Fig. 1.

\section{Grouped Perceptions}

The characteristics listed earlier were grouped into categories as demonstrated by MacKay 2004, and is shown in -Table 2: the breadth of professional outlook, the degree of patient interaction, the projected professional image, the perception of own professional status, the skills for a wide professional remit, the level of rapport with patient and colleagues, and the degree of professional interdependence.

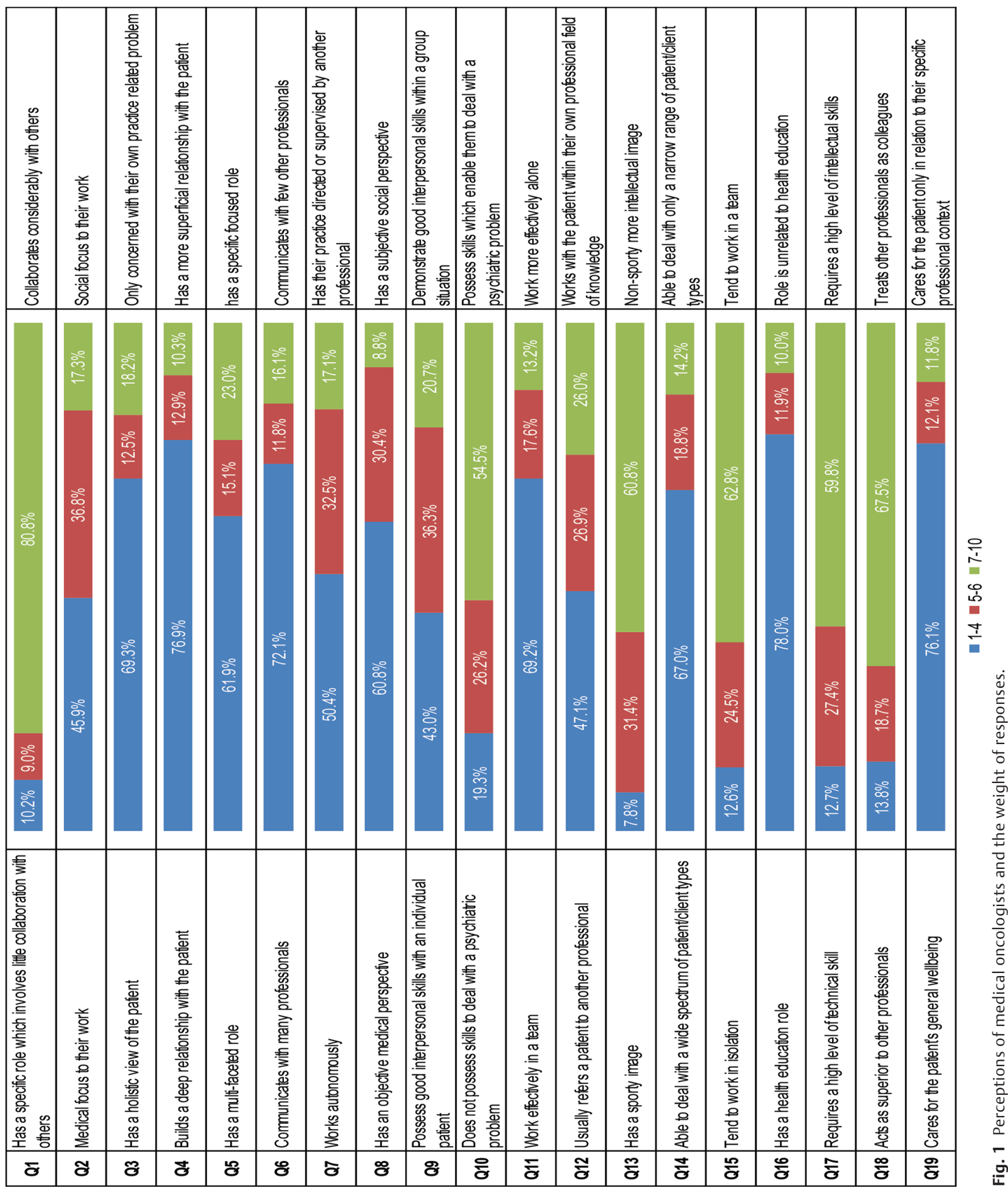


Table 2 Categories of perceptions

\begin{tabular}{|c|}
\hline $\begin{array}{l}\text { I. Breadth of professional outlook: nos. 2, 3, 5, 6, } 8 \text {, } \\
\text { and } 11\end{array}$ \\
\hline 2-medical vs. social focus to work \\
\hline 3-holistic view vs. concerned with their own practice \\
\hline 5-multi-faceted vs. focused role \\
\hline 6-communicates with many vs. few professionals \\
\hline 8-objective vs. subjective medical perspective \\
\hline 11-work effectively in a team vs. alone \\
\hline II. Degree of patient interaction: nos. 4 and 19 \\
\hline 4-deep vs. superficial relationship with the patient \\
\hline $\begin{array}{l}\text { 19-cares for patient's general well-being vs. only in } \\
\text { relation to specific professional context }\end{array}$ \\
\hline III. Projected professional image: no. 13 \\
\hline $\begin{array}{l}\text { 13-has a sporty image vs. nonsporty, more } \\
\text { intellectual image }\end{array}$ \\
\hline IV. Perception of own profession status: no. 18 \\
\hline 18 -acts as superior vs. treats others as colleagues \\
\hline $\begin{array}{l}\text { V. Possess skills for a wide professional remit: nos. } 10 \text {, } \\
14,16 \text {, and } 17\end{array}$ \\
\hline $\begin{array}{l}10-\text { does not possess skills to deal with a psychiatric } \\
\text { problem vs. possess skills }\end{array}$ \\
\hline $\begin{array}{l}\text { 14-able to deal with a wide spectrum vs. narrow } \\
\text { range of patients }\end{array}$ \\
\hline 16-health education role vs. none \\
\hline $\begin{array}{l}\text { 17-requires high level of technical skills vs. } \\
\text { intellectual }\end{array}$ \\
\hline $\begin{array}{l}\text { VI. Level of rapport with patient and colleagues: } \\
\text { nos. } 1,9 \text {, and } 15\end{array}$ \\
\hline 1-little vs. collaborates considerably with others \\
\hline $\begin{array}{l}\text { 9-possess good interpersonal skills with an individ- } \\
\text { ual patient vs. within a group }\end{array}$ \\
\hline 15-tend to work in isolation vs. team \\
\hline $\begin{array}{l}\text { VII. Degree of professional interdependence: } \\
\text { nos. } 7 \text { and } 12\end{array}$ \\
\hline 7-works autonomously vs. directed by another \\
\hline $\begin{array}{l}\text { 12-usually refers a patient vs. works with a patient } \\
\text { within their own professional field of knowledge }\end{array}$ \\
\hline
\end{tabular}

Note: Adapted with permission from MacKay. ${ }^{12}$

In terms of breadth of professional outlook, medical oncologists were deemed to have a medical rather than social focus, holistic care, a multifaceted role, communication with many other professionals, and work more effectively in a team.

As to the degree of patient interaction, medical oncologists are perceived to have deep relationships with their patients and care for their general well-being.

The projected professional image of medical oncologists is of a nonsporty, intellectual type.

With regard to the perception of own profession status, medical oncologists do not consider themselves as superior, but rather treat other physicians as colleagues.

As to the skills for a wide professional scope of responsibility, medical oncologists have the skills to deal with a psychiatric problem and are able to deal with a wide spectrum of patients. They also have a health education role and require a high level of intellectual skills.

In terms of the level of rapport with colleagues, medical oncologists collaborate more with others and possess good interpersonal skills with an individual patient, but are also good within a group, especially as they are more commonly perceived to work in a team setup.

With regard to professional interdependence, medical oncologists are viewed as autonomous workers, but usually refer patients to other professionals as well.

\section{Additional Perceptions}

Respondents were allowed to write down positive or negative qualities that would best describe medical oncologists and the values that they should have, other than those already cited in the questionnaire. Their responses are represented in - Table 3.

\section{Hindrances to Referral to Medical Oncologists}

Respondents were asked to cite any factors that would hinder them from referring to medical oncologists, if any. Responses were grouped into the following categories: financial reasons, technical/logistical factors, patient/family factors, and physician factors. Their responses are listed in - Table 4 .

Other respondents explained that they always refer to medical oncologists when indicated, but they only encounter hesitations in their personal choice of whom among the medical oncologists they would refer to. It was stated that "some (not many) mostly seniors, tend to change management plan based on their experience and choice without collaboration or multidisciplinary team (MDT) consultation." Another stated that the hindrance was a characteristic perceived as the practice of "making a business-like profession." Another comment was, "Some oncologists overdo management even on stage IV or terminal cases, knowing the only treatment left is palliative only." It was stated that, "This situation drains the family finances because of the hope that was influenced by the oncologist." Another respondent expressed that, "In our setting where medicine is not socialized or free, I hope the oncologist does not assume an opportunistic role and let the patient and his family decide by giving more objective results of the treatment.

Lastly, one respondent expressed that some degree of bias was practiced in the answering of the questionnaire in consideration of the subjects as colleagues in the same institution and familiarity with the practice ethics of the medical oncologists of the hospital.

\section{Other Comments}

Respondents were allowed to express additional comments; these are listed in $\boldsymbol{- T a b l e ~} \mathbf{5}$.

\section{Discussion}

\section{The Respondents}

The UST hospital has a formal multidisciplinary team (MDT) and multidisciplinary meeting system in place. Almost all 
Table 3 Additional traits cited by respondents

\begin{tabular}{|c|c|}
\hline Positive & Negative \\
\hline 1. Able to collaborate and speak to primary attending & 1. Better time management \\
\hline 2. Able to connect to relatives as well & 2. Enthusiasm must be tempered with reality \\
\hline 3. Able to deal with awkward/lowest situation professionally & $\begin{array}{l}\text { 3. Having too many commitments at one time, } \\
\text { leading to unavailability }\end{array}$ \\
\hline 4. Able to offer best supportive care as a management option & 4. Must not be keen on financial compensation \\
\hline 5. Assertive & $\begin{array}{l}\text { 5. Should always consider the economic impact } \\
\text { of treatment and be able to discuss on cost-ef- } \\
\text { fective treatment }\end{array}$ \\
\hline 6. Available for any inquiry from patient and/or colleagues & $\begin{array}{l}\text { 6. Should be patient's advocate, find ways to help } \\
\text { patient }\end{array}$ \\
\hline 7. Compassionate & 7. Should be upfront about chances of recovery \\
\hline 8. Decisive & $\begin{array}{l}\text { 8. Should put into practical context/perspective } \\
\text { trial or study results on survival }\end{array}$ \\
\hline 9. Direct personal relation with patient & $\begin{array}{l}\text { 9. Should show compassion and important } \\
\text { bedside care, especially to those undergoing } \\
\text { chemotherapy }\end{array}$ \\
\hline 10. Empathy & $\begin{array}{l}\text { 10. Should show empathy by time spent listening } \\
\text { to patient }\end{array}$ \\
\hline 11. Exhibit Christian values & 11. Talks too fast, barely listens \\
\hline \multicolumn{2}{|l|}{ 12. Generous } \\
\hline \multicolumn{2}{|l|}{ 13. Genuinely caring } \\
\hline \multicolumn{2}{|l|}{ 14. God-fearing } \\
\hline \multicolumn{2}{|l|}{ 15. Good understanding of ethics } \\
\hline \multicolumn{2}{|l|}{ 16. Honesty to patient } \\
\hline \multicolumn{2}{|l|}{ 17. Mobilizes/enables optimal use of patient/family resources } \\
\hline \multicolumn{2}{|l|}{ 18. Psychosocial skills } \\
\hline \multicolumn{2}{|l|}{ 19. Religious/spiritual } \\
\hline \multicolumn{2}{|l|}{ 20. Researcher } \\
\hline 21. Very knowledgeable about management options & \\
\hline
\end{tabular}

of the UST hospital medical staff and trainees have been involved in an MDT approach. The medical staff of this institution is affiliated with other hospitals and has exposure to medical oncologists elsewhere; hence, their perceptions may not entirely reflect their thoughts on medical oncologists in the UST hospital alone. Medical trainees comprise the majority of this study's respondents. Residents and fellows of this institution may only have perceptions of medical oncologists of this institution if they have had no prior training (internship or residency) in other hospitals. Canadian health commissioner Roy Romanow in his 2002 Report on the Future of Health Care in Canada says, "If health care providers are expected to work together and share expertise in a team environment, it makes sense that their education and training should prepare them for this type of working arrangement."3

\section{Perceptions of Medical Oncologists}

Perception surveys are able to provide feedback on the strengths and weakness of the specialty. Better understanding of how one's practice is perceived by others, especially if this does not match one's self-assessment, may help one improve on the negative points and reinforce the positive points. Interprofessional education in clinical practice would improve patient care, safety, and professional rapport. ${ }^{4}$

There were no opposing perceptions between surgical and other medical specialties. They were generally united with regard to qualities of medical oncologists in terms of breadth of professional outlook, degree of patient interaction, projected professional image, perception of own professional status, possession of skills for a wide professional scope of responsibility, level of rapport with patient and colleagues, and degree of professional interdependence.

\section{Positive Traits}

The choices made on the questionnaire and additional comments were wholly positive and are in line with the European Society of Medical Oncology/American Society of Clinical Oncology Global Curriculum that states that a medical oncologist should be an "effective communicator, collaborator in the treatment team, a health care manager, a health advocate for the patient and community, and a scholar with lifelong commitment and high professional ethics and standards." ${ }^{3}$ 
Table 4 Hindrances to referral to medical oncologists

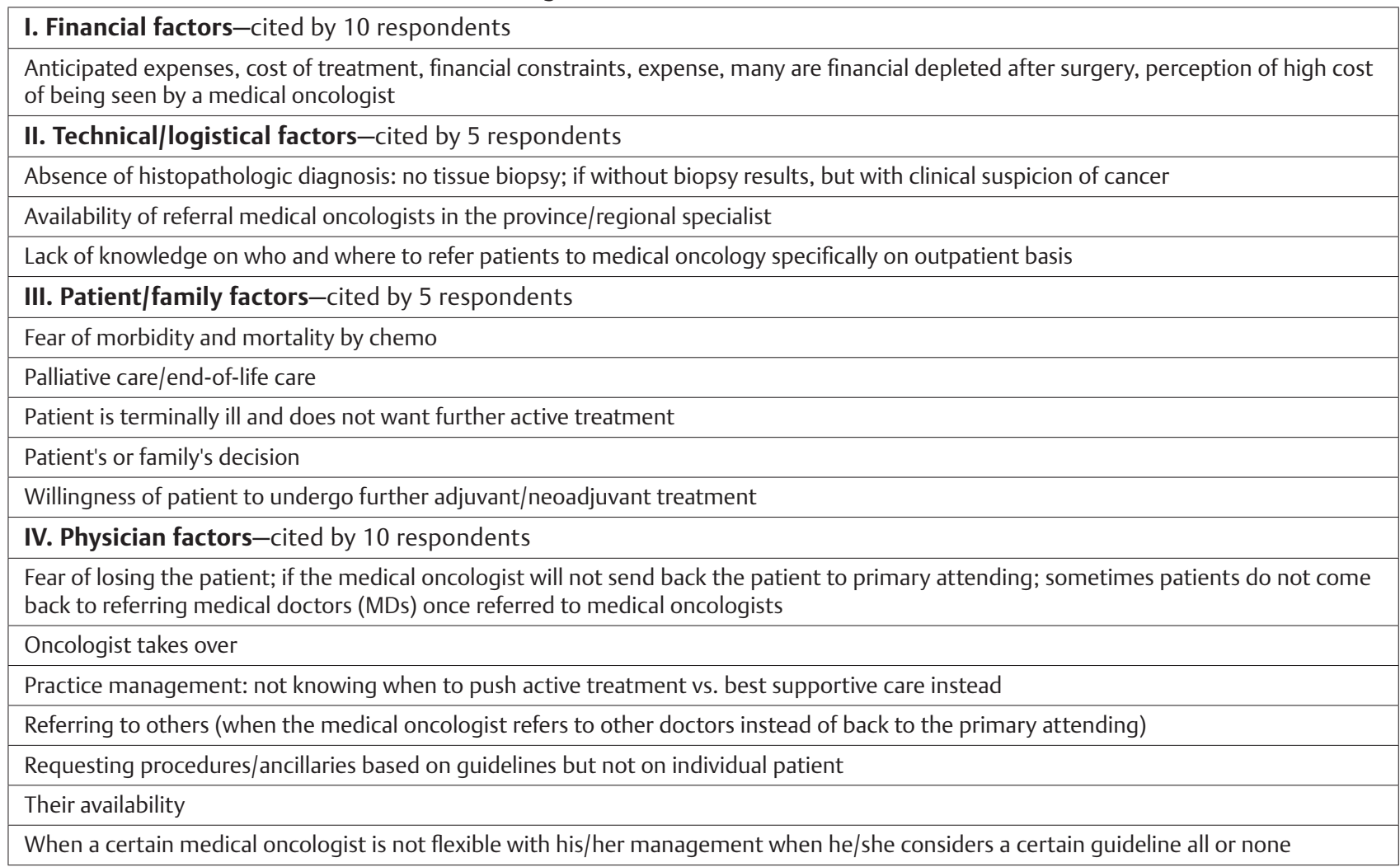

Table 5 Other comments

\begin{abstract}
1. Based on my personal experience, medical oncologists possess characteristics that not only allow them to treat patients, but also empathize with them and their families. Most of their patients have really struggled with their condition; hence, I have observed that most medical oncologists become a very important support system for their patients. Most of them (doctors) also take a multidisciplinary approach when it comes to therapy.
\end{abstract}

2. Cancer cases need multidisciplinary care, especially advanced cancer.

3. Help patient toward a peaceful death.

4. I think medical oncology has a wide range of holistic specialty which involves individual care for patients with good interdepartmental relations in treating cancer.

5. In the University of Santo Tomas Hospital, I see that medical oncologists usually work in a multidisciplinary setting which is good for holistic care.

6. Medical oncologists have an essential role in managing patients aside from the medical aspect of the patient. As internists, we trust and refer to them especially when considering malignancy.

7. Medical oncologists in our institution are courteous people who know how to refer patients to other oncology specialties. Even though they know they can treat the patients themselves, they have the courtesy to inform other services who are the primary physicians of the case before intervening.

8. Medical oncology helps us to manage patients holistically.

9. Reduce the fee for chemotherapy session.

\section{Negative Traits}

With regard to the negative traits, these are also consistent with those cited in opinion articles by Sircus, ${ }^{5}$ Tips, ${ }^{6}$ and Sessions. ${ }^{7}$ Fear of the morbidity and mortality of chemotherapy may be equated with the concept that being referred to a medical oncologist is "scary."7 The description "talks too fast, does not listen" is a demonstration of lapses or inadequacy of communication due to lack of concern or lack of communicative skills. ${ }^{7}$ On not being keen on financial compensation and considerate of the economic impact of treatment is similar to Tips' article that medical oncologists have a profit agenda. ${ }^{6}$

The comment that systemic treatment in the palliative setting "drains the family finances because of the hope that was influenced by the oncologist" is related to Sircus' article that stated that oncologists are "domineering" and are able to convince patients to undergo chemotherapy by "preying" on their insecurities. ${ }^{5}$ This is related to the comments that medical oncologists should be upfront about chances of recovery and put into practical perspective clinical trial survival results.

\section{Hindrances}

A main hindrance to referral to medical oncologists is the perceived financial burden to the patient. This, along with the other factors cited, is consistent with previous US studies enumerating underprivileged settings, patient's choice, lack of access to provider of adjuvant treatment, differing opinions between surgeons and medical oncologists on treatment guidelines, and hesitation in administering chemotherapy to the elderly and patients with comorbidities. ${ }^{8-10}$ The difference 
locally is that the family's decision also factors into the decision to seek consultation or treatment, due to the Filipino culture.

These apprehensions need to be addressed because not referring to a medical oncologist might lead to inadequate cancer management. A US study in 2000 by Siminoff et al emphasized, "Decisions to refer patients to other physicians for care or consultation are an important component of the provision of appropriate care for cancer patients." ${ }^{11}$ Identifying these problems as reported in this article is the first step toward providing solutions.

Awareness of these perceptions of their professional roles by the individual medical oncologists of this institution and by the section of medical oncology would improve the professional relationships between and among specialties in the UST hospital.

\section{Conclusion}

Majority of surgical and other medical specialties consider medical oncologists to collaborate considerably with others; have a medical focus to their work; have a holistic view of the patient; build a deep doctor-patient relationship; have a multifaceted role; communicate with many professionals; work autonomously; have an objective medical perspective; possess good interpersonal skills with individual patients; possess skills to deal with a psychiatric problem; work effectively in a team; usually refer a patient to another professional; have a nonsporty, more intellectual image; able to deal with a wide range of patient types; tend to work in a team; have a health education role; require a high degree of intellectual skills; treat other professionals as colleagues; and care for the patient's general well-being.

Recurring statements on qualities that medical oncologists have or should have are compassion and empathy. Other characteristics reported were ability to collaborate and speak to primary attending physicians, ability to connect to relatives, ability to deal with an awkward/lowest situation professionally, ability to offer the best supportive care as a management option, being assertive, available for any inquiry from patient and/or colleagues, being decisive, having direct personal relation with patient, exhibiting Christian values, being generous, being genuinely caring, being god-fearing, having a good understanding of ethics, honesty to the patient, mobilizing/enabling optimal use of patient/family resources, having psychosocial skills, being religious/spiritual, and being a researcher. It was also stated that medical oncologists are very knowledgeable about management options, but enthusiasm must be tempered with reality.

Points that medical oncologists should improve upon are the following: better time management; having too many commitments at one time, leading to unavailability; not being keen on financial compensation; always considering the economic impact of treatment and being able to discuss cost-effective treatment; being the patient's advocate; finding ways to help patient; being upfront about the chances of recovery; putting into practical context/perspective trial or study results on survival; showing compassion and important bedside care, especially to those undergoing chemotherapy; and showing empathy by time spent listening to the patient, instead of talking too fast and barely listening.

The most commonly cited hindrance to referral to medical oncologists is the anticipated financial burden on the patient. Other impediments mentioned were technical or logistical factors, patient or family factors, and physician factors.

\section{Conflict of Interest}

None declared.

\section{Acknowledgments}

The authors thank Dr. Stuart MacKay for his permission to use the Role Perception Questionnaire he developed and Mrs. Diana Locayon-Caudilla who was the designated study statistician.

\section{References}

1 Directory of Doctors. Philippine Society of Medical Oncology Web site. https://www.psmo.org.ph/psmodoctors2018database-all. Accessed July 2019

2 ESMO/ASCO recommendations for a Global Curriculum in medical oncology edition 2016. European Society of Medical Oncology Web site. Available at: https://www.esmo.org/ career-development/global-curriculum-in-medical-oncology. Accessed March 31, 2019

3 Romanow R. Building on values: the future of health care in Canada. Final report of the Commission of the Future of Health Care in Canada. Available at: https://qspace.library.queensu. ca/bitstream/handle/1974/6882/BuildingOnValues.pdf?sequence $=5$. Published November 2002. Accessed March 31, 2019

4 Moriel D, Felix, K, Quinlan, P. Roles and responsibilities: asking nurses and physicians what they know, do not know and want to know about each other's profession. J Res Interprof Pract Educ 2017;7.1:1-18

5 Sircus M. Oncologists are the worst people to treat cancer. Available at: http://drsircus.com/cancer/oncologists-worstpeople-treat-cancer/. Published September 28, 2012. Accessed March 31, 2019

6 Tips S. Scientific terrorism. Available at: http://www.newswithviews.com/Tips/scott.htm. Published December 2, 2007. Accessed March 31, 2019

7 Sessions RB. Referral to the oncologist once cancer is suspected: scary. Available at: https://www.psychologytoday. com/blog/the-cancer-experience/201406/referral-the-oncologist-once-cancer-is-suspected-scary. Published June 28, 2014.Accessed March 31, 2019

8 Jagsi R, Abrahamse P, Morrow M, Hamilton AS, Graff JJ, Katz SJ. Coordination of breast cancer care between radiation oncologists and surgeons: a survey study. Int J Radiat Oncol Biol Phys 2012;82(5):2072-2078

9 Keating NL, Landrum MB, Klabunde CN, et al. Adjuvant chemotherapy for stage III colon cancer: do physicians agree about the importance of patient age and comorbidity? J Clin Oncol 2008;26(15):2532-2537

10 Schroen AT, Detterbeck FC, Crawford R, Rivera MP, Socinski MA. Beliefs among pulmonologists and thoracic surgeons in the therapeutic approach to non-small cell lung cancer. Chest 2000;118(1):129-137

11 Siminoff LA, Zhang A, Saunders Sturm CM, Colabianchi N. Referral of breast cancer patients to medical oncologists after initial surgical management. Med Care 2000;38(7):696-704

12 Mackay S. The role perception questionnaire (RPQ): a tool for assessing undergraduate students' perceptions of the role of other professions. J Interprofessional Care 2004;18(3):289-301 